Primljen / Received: 21.10.2011.

Ispravljen / Corrected: 8.2.2012.

Prihvaćen / Accepted: 21.2.2012.
Dostupno online / Available online: 15.3.2012.

\section{Steel plate elements loaded in their plane - buckling factors and critical stresses}

\section{Authors:}

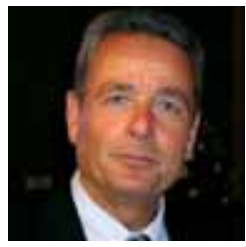

Mehmed Čaušević, Mladen Bulić

Subject review

\section{Steel plate elements loaded in their plane - buckling factors and critical stresses}

The stability of steel plate elements subjected to loading in their own plane is analyzed in the paper. The notion of elastic critical plate buckling stress is explained, and the related buckling factor is defined. The analysis of buckling factor and critical plate element stress for arbitrary boundary conditions, arbitrary stress distribution, and any plate length to width ratio, is presented by means of an analytic procedure and using a specialized computer program EBPlat, which is based on the European standard EN 1993-1-5.

Key words:

plate girders, critical stress, buckling factor, plate element stability, computer program EBPlate

Pregledni rad

Mehmed Čaušević, Mladen Bulić

\section{Čelični plošni elementi opterećeni u svojoj ravnini: faktori izbočivanja i kritična naprezanja}

Assistant Prof. Mladen Bulić, PhD. CE University of Rijeka

Faculty of Civil Engineering mladen.bulic@gradri.hr
U radu je analizirana stabilnost čeličnih plošnih elemenata opterećenih u svojoj ravnini. Detaljno je objašnjen pojam elastičnog kritičnog naprezanja izbočivanja ploče te s njim u vezi i faktor izbočivanja. Prikazan je izračun faktora izbočivanja i kritičnog naprezanja plošnog elementa za proizvoljne rubne uvjete, proizvoljnu raspodjelu naprezanja i bilo koji odnos dužine i širine ploče analitičkim postupkom te primjenom specijaliziranog računalnog programa EBPlat, koji je utemeljen na europskoj normi EN 1993-1-5.

Ključne riječi:

plošni nosači, kritično naprezanje, faktor izbočivanja, stabilnost plošnog elementa, računalni program EBPla

Übersichtsarbeit

Mehmed Čaušević, Mladen Bulić

\section{In ihrer Ebene belastete Stahlblechelemente - Knickfaktoren und kritische} Beanspruchungen

In der Arbeit wird die Stabilität von Stahlblechelementen analysiert, die in ihrer Ebene belastet wurden. Der Begriff der elastischen kritischen Beanspruchung des Blechknicks und der damit verbundene Knickfaktor werden detailliert erläutert. Dargestellt ist die Berechnung des Knickfaktors und der kritischen Beanspruchung der Blechelemente bei willkürlichen Randbedingungen, willkürlichen Beanspruchungsverteilung und einem beliebigen Verhältnis der Blechbreite und - länge durch Anwendung des analytischen Verfahrens und der spezialisierten Software EBPlate, die auf der Europäischen Norm EN 1993-1-5 beruht. 


\section{Introduction}

Structural steel elements, rolled or welded, can be taken as if they were made of plate elements, which can be either internal or external, cf. Figure 1. As plate elements of class 4 cross sections are relatively thin, with pronounced local slenderness, they can locally buckle when subjected to compression in their own plane (as a consequence of longitudinal compressive force acting on the entire cross section and/or as a consequence of bending), which is why their reduced cross sectional value is adopted in the analysis, cf. Table 1 [1, 2]. Local buckling of a plate element, regardless of its position within the cross section, limits resistance to longitudinal force of the entire cross section, or of the entire element, or its resistance to bending, and prevents achievement of cross sectional flow. Premature failure due to local buckling effect can be avoided by limiting width to thickness ratio of a cross-sectional plate element, and by transverse and longitudinal bracing. This problem is controlled by introduction of the buckling factor $k_{\sigma}$, cf. Table 1.

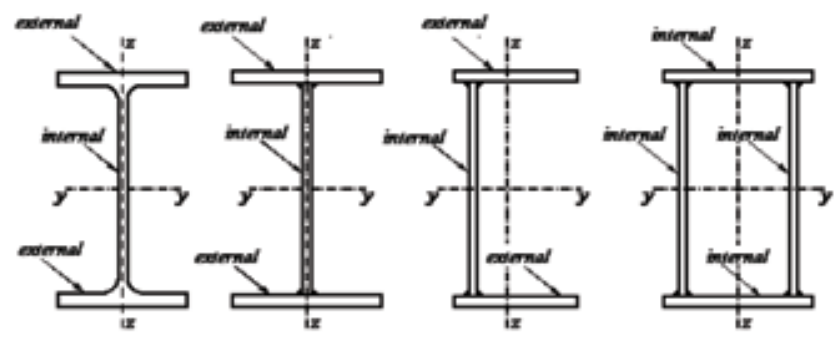

Figure 1. Plate elements (rolled or welded) of the girder

The way in which values of the buckling factor, $k_{\sigma}$ from Table 1 are generated, will be shown in the following text. An example will be presented with boundary conditions for $k_{\sigma}=4,0$ from Table 1, and this first analytically, and then using the special software package EBPlate (Elastic Buckling of Plate) [3].

Table 1. Values of buckling factor $k_{\sigma}$ for internal element in compression [1]

\begin{tabular}{|l|l|l|}
\hline \multicolumn{2}{|c|}{$\begin{array}{c}\text { Stress distribution } \\
\text { (compression is positive) }\end{array}$} & \multicolumn{3}{|c|}{ Efective width $b_{\text {eff }}$} \\
\hline$\sigma_{1}$ & $\begin{array}{l}\psi=1: \\
b_{\text {eff }}=\rho \bar{b} \\
b_{e 1}=0,5 b_{\text {eff }} \quad b_{e 2}=0,5 b_{\text {eff }}\end{array}$ \\
\hline
\end{tabular}

Therefore, to understand the way in which the class 4 cross section is defined, i.e. the way in which the area of the class 4 cross section is reduced (determination of the buckling factor $\left.k_{\sigma}\right)$, it is significant to know the theory of stability of plate elements loaded in their plane, and this in the way this theory is presented in structural mechanics. This theory can also be applied in the following cases:

- lateral torsional buckling of elements (EN 1993-1-1)[4],

- stability of compressed steel members composed of plate elements (webs and flanges) (EN 1993-1-1) [5, 6],

- analysis of stability of deep plate girders used on bridges (EN 1993-1-5) [2,7], Figure 2,

- analysis of stability of plate girders with bracing (EN 1993-1-5) [2].

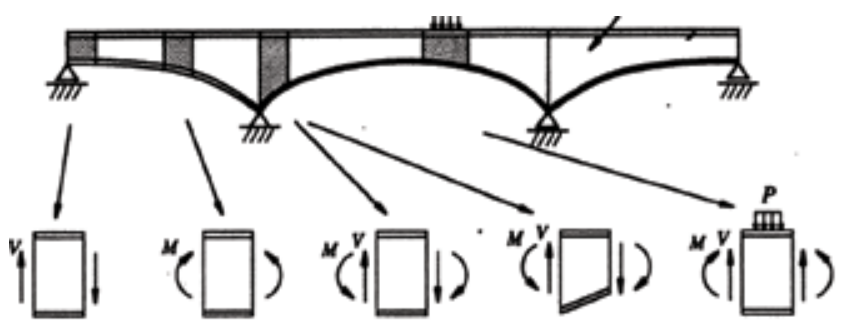

Figure 2. Deep plate girder segments loaded in their plane

\section{General theory of stability of plate girders}

\subsection{Bending stress}

The web shown in Figure 3 is considered. According to the general bending theory for thin plates, a differentially small part of this web (shown in Figures 4 and 5) is used to generate the differential equation for deflection of plate elements $[6,8]$, using equilibrium conditions in the straight line perpendicular to the studied plane:

$q \cdot d x \cdot d z-D\left(\frac{\partial^{4} w}{\partial x^{4}}+2 \frac{\partial^{4} w}{\partial x^{2} \partial z^{2}}+\frac{\partial^{4} w}{\partial z^{4}}\right) d x \cdot d z=0$

$q \cdot d x \cdot d z-D \cdot \Delta \Delta w \cdot d x \cdot d z=0$

$Y_{(q)}-D \cdot \Delta \Delta w \cdot d x \cdot d z=0$

where:

$w$ - displacement perpendicular to the plane $\mathrm{dx} \cdot \mathrm{dz}$ $Y_{(q)}$ - load perpendicular to the plane $d x \cdot d z, Y_{(q)}=q \cdot d x \cdot d z$ $D$ - flexural stiffness of a plate element

$D=\frac{E h^{3}}{12\left(1-v^{2}\right)}$,

where:

$v$ - Poisson ratio,

h - plate element thickness,

$E$ - elastic modulus. 


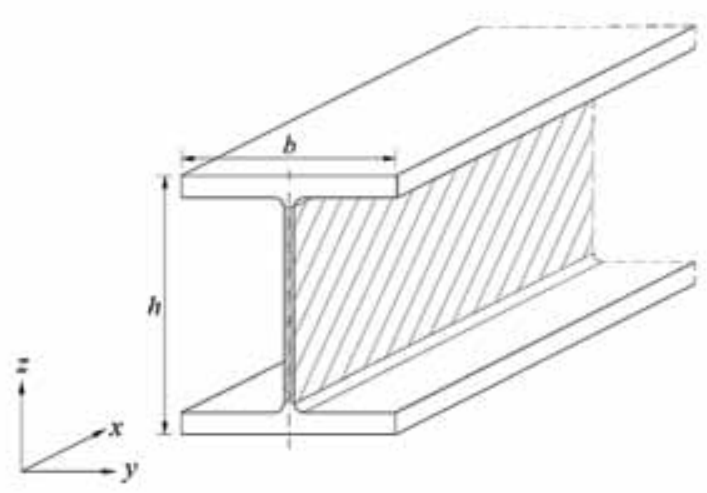

Figure 3. Studied part of a thin steel element

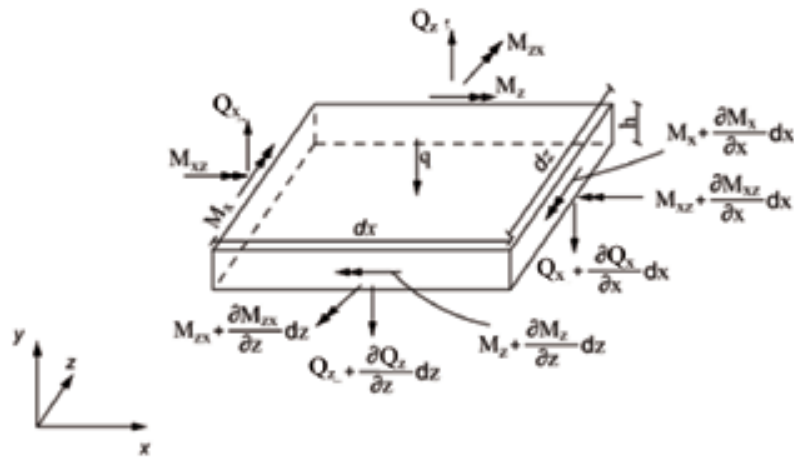

Figure 4. Differentially small part of the web

\subsection{Plane stress}

In this case, the differentially small element is affected solely by forces situated in the central plane of the element (Figure 5), and these are $[6,8]$ :

$$
N_{x}, \quad N_{z}, \quad T_{x z}=T_{z x}=T
$$

In the central plane of the plate (Figure 5), the transverse forces are obtained through integration of stress along the height of the cross section. If it is assumed that $d x=d z=1$, the values of these forces are:

$$
\begin{aligned}
& N_{x}=\int_{-h / 2}^{h / 2} \sigma_{x} \cdot d y=\sigma_{x} \cdot h \\
& N_{z}=\int_{-h / 2}^{h / 2} \sigma_{z} \cdot d y=\sigma_{z} \cdot h \\
& T_{x z}=T_{z x}=T=\int_{-h / 2}^{h / 2} \tau_{x z} \cdot d y=\int_{-h / 2}^{h / 2} \tau_{z x} \cdot d y=\tau_{x z} \cdot h
\end{aligned}
$$

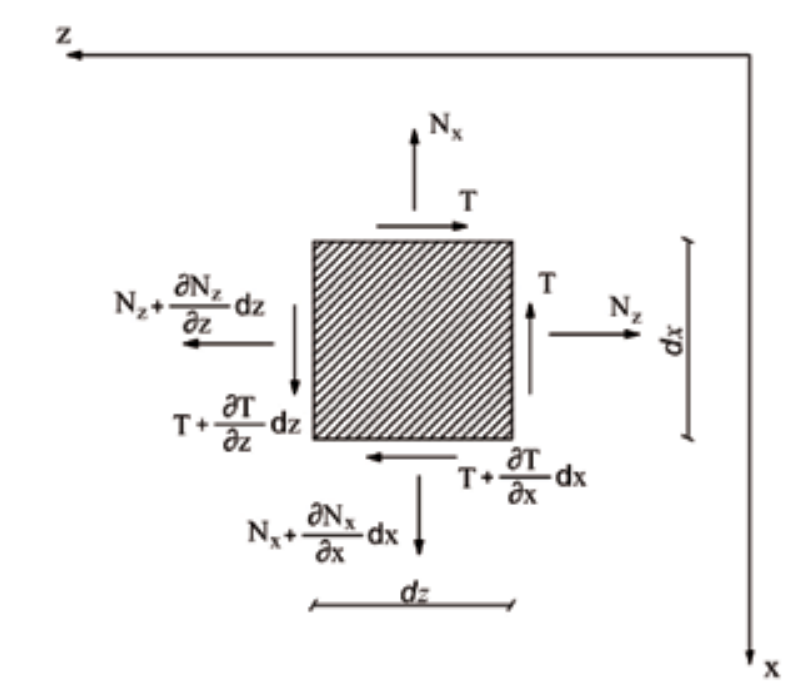

Figure 5. Central plane of the plate

The influence of longitudinal forces is shown in Figure 6. As the value $\theta_{x}$ is small, it can be assumed that:

$$
\begin{aligned}
& \sin \theta_{z} \cong \operatorname{tg} \theta_{z} \cong \theta_{z}=\frac{\partial w}{\partial z} \\
& \sin \theta_{x} \cong \operatorname{tg} \theta_{x} \cong \theta_{x}=\frac{\partial w}{\partial x}
\end{aligned}
$$

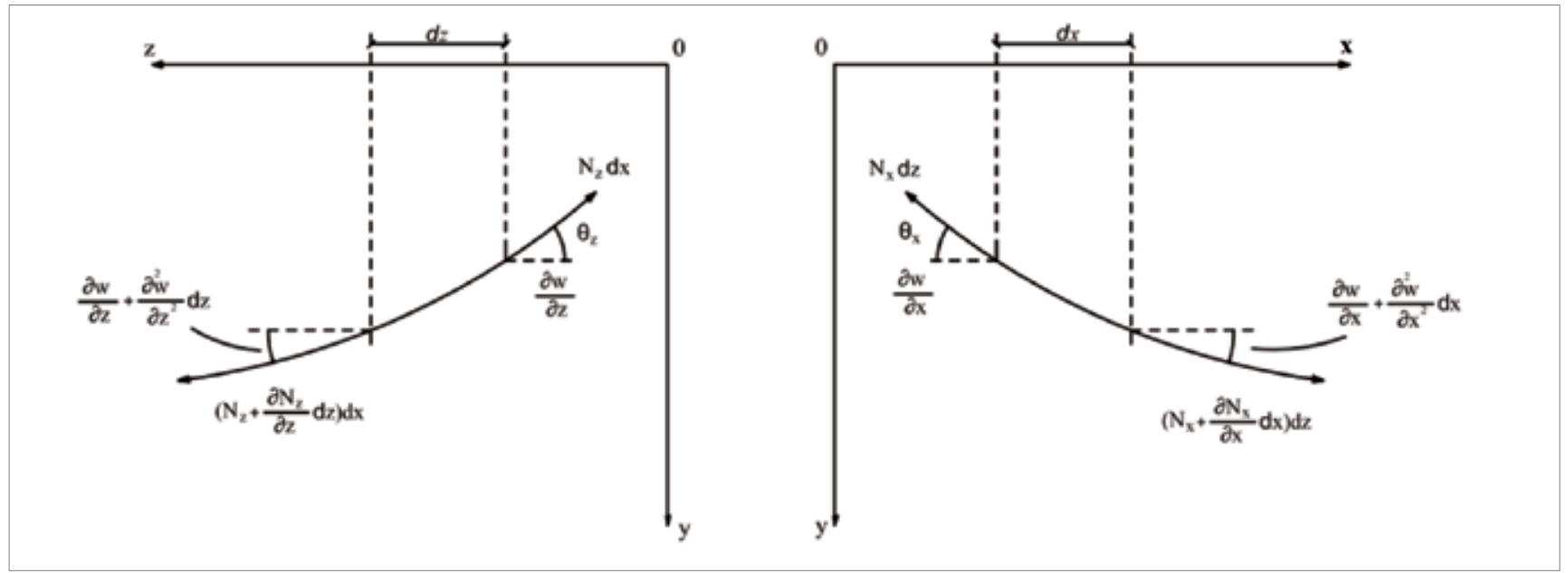

Figure 6. Influence of longitudinal forces 
Then the sum of longitudinal forces projected on the $y$ axis is:

$$
\begin{aligned}
& \sum Y_{(N)}=-N_{x} \frac{\partial w}{\partial x} \cdot d z+\left(N_{x}+\frac{\partial N_{x}}{\partial x} d x\right) d z \cdot\left(\frac{\partial w}{\partial x}+\frac{\partial^{2} w}{\partial x^{2}} d x\right)- \\
& -N_{z} \frac{\partial w}{\partial z} \cdot d x+\left(N_{z}+\frac{\partial N_{z}}{\partial z} d z\right) d x \cdot\left(\frac{\partial w}{\partial z}+\frac{\partial^{2} w}{\partial z^{2}} d z\right)
\end{aligned}
$$

After arrangement and neglect of small values of higher order, we obtain:

$\sum Y_{(N)}=\left(\frac{\partial N_{x}}{\partial x} \cdot \frac{\partial w}{\partial x}+\frac{\partial N_{z}}{\partial z} \cdot \frac{\partial w}{\partial z}+N_{x} \frac{\partial^{2} w}{\partial x^{2}}+N_{z} \frac{\partial^{2} w}{\partial z^{2}}\right) d x \cdot d z$

The influence of transverse forces is shown in Figure 7 which can be used to form the following relation:

$\sum Y_{(T)}=-T \frac{\partial w}{\partial x} \cdot d x+\left(T+\frac{\partial T}{\partial z} d z\right) d x \cdot\left(\frac{\partial w}{\partial x}+\frac{\partial^{2} w}{\partial x \cdot \partial z} d z\right)-$

$-T \frac{\partial w}{\partial z} \cdot d z+\left(T+\frac{\partial T}{\partial x} d x\right) d z \cdot\left(\frac{\partial w}{\partial z}+\frac{\partial^{2} w}{\partial x \cdot \partial z} d x\right)$.

Once influences of small values of higher order are neglected, the following can be obtained from the preceding equation:

$\sum Y_{(T)}=\left(\frac{\partial T}{\partial x} \cdot \frac{\partial w}{\partial z}+\frac{\partial T}{\partial z} \cdot \frac{\partial w}{\partial x}+2 T \frac{\partial^{2} w}{\partial x \partial z}\right) d x \cdot d z$

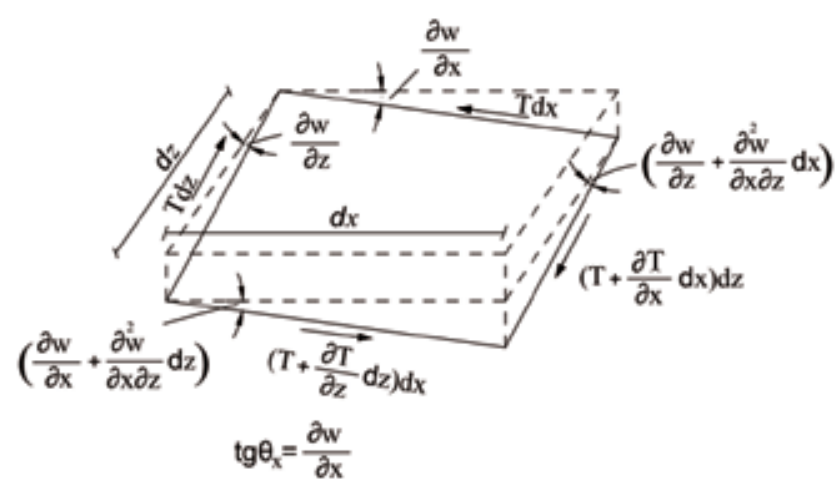

Figure 7. Influence of transverse forces

\subsection{Summation of bending stress and plane stress}

We can now formulate the equilibrium condition for all forces acting on a differentially small element (bending stress plus plane stress) in the straight line of the $y$ axis, the sum of equations (1), (2) and (3):

$\sum Y=\sum Y_{(q)}+\sum Y_{(N)}+\sum Y_{(T)}=$

$=q \cdot d x \cdot d z-D \cdot \Delta \Delta w \cdot d x \cdot d z+\left(\frac{\partial N_{x}}{\partial x} \cdot \frac{\partial w}{\partial x}+\frac{\partial N_{z}}{\partial z} \cdot \frac{\partial w}{\partial z}+N_{x} \frac{\partial^{2} w}{\partial x^{2}}+N_{z} \frac{\partial^{2} w}{\partial z^{2}}\right) d x d z+$

$$
+\left(\frac{\partial T}{\partial x} \cdot \frac{\partial w}{\partial z}+\frac{\partial T}{\partial z} \cdot \frac{\partial w}{\partial x}+2 T \frac{\partial^{2} w}{\partial x \partial z}\right) d x d z=0 .
$$

If this equilibrium condition is multiplied with $1 / d x d z$, we obtain:

$q-D \cdot \Delta \Delta w+N_{x} \frac{\partial^{2} w}{\partial x^{2}}+N_{z} \frac{\partial^{2} w}{\partial z^{2}}+2 T \frac{\partial^{2} w}{\partial x \partial z}+\left(\frac{\partial N_{x}}{\partial x}+\frac{\partial T}{\partial z}\right) \frac{\partial w}{\partial x}+\left(\frac{\partial N_{z}}{\partial z}+\frac{\partial T}{\partial x}\right) \frac{\partial w}{\partial z}=0$.

Members of the preceding equation

$\left(\frac{\partial N_{x}}{\partial x}+\frac{\partial T}{\partial z}\right) \frac{\partial w}{\partial x} \quad$ i $\left(\frac{\partial N_{z}}{\partial z}+\frac{\partial T}{\partial x}\right) \frac{\partial w}{\partial z}$

are small values of higher order that have been neglected. The transverse load $q$ acting on the web (non existent in this case) is also omitted. At that, it is also important to note the change of sign of longitudinal forces in case when these forces are compressive. In the end, the following plate buckling equation is obtained:

$-D \nabla w+\left(N_{x} \frac{\partial^{2} w}{\partial x^{2}}+2 T \frac{\partial^{2} w}{\partial x \partial z}+N_{z} \frac{\partial^{2} w}{\partial z^{2}}\right)=0$.

Boundary conditions for two basic cases of plate support are:

- pinned support $w=0$ and $w^{\prime \prime}=0$

- fixed plate support $w=0$ and $w^{\prime \prime}=0$

The simplest case of buckling of a pinned rectangular plate will now be considered. This plate may be an I-section web, which is affected by a uniform uniaxial compressive load, as shown in Figure 8.

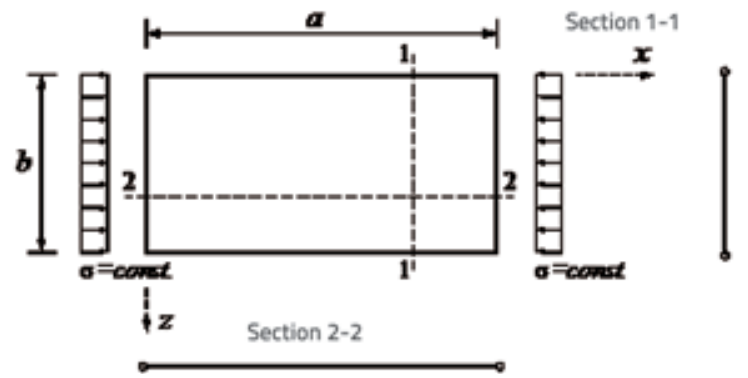

Figure 8. Pinned rectangular plate (e.g., I-section web) subjected to a uniformly distributed uniaxial compressive load

As $N_{x}=\sigma \cdot h, N_{z}=0$ and $T=0$ in case of a compressive longitudinal force (Figure 8), the equation (4) is reduced to:

$D \nabla w+\sigma \cdot h \frac{\partial^{2} w}{\partial x^{2}}=0$.

This equation can be solved in form of a double trigonometric order:

$w=\sum_{m=1}^{\infty} \sum_{n=1}^{\infty} c_{m n} \cdot \sin \frac{m \pi z}{a} \cdot \sin \frac{n \pi x}{b}$

whose derivations are: 
$\frac{\partial^{2} w}{\partial z^{2}}=-\sum_{m=1}^{\infty} \sum_{n=1}^{\infty} c_{m n} \cdot\left(\frac{m \pi}{a}\right)^{2} \cdot \sin \frac{m \pi z}{a} \cdot \sin \frac{n \pi x}{b}$

$\left.\nabla w=\sum_{m=1}^{\infty} \sum_{n=1}^{\infty} c_{m n}\left[\left(\frac{m \pi}{a}\right)^{2}+\left(\frac{n \pi}{b}\right)^{2}\right]^{2} \cdot \sin \frac{m \pi z}{a} \cdot \sin \frac{n \pi x}{b}\right\}$

By inserting (6) into (5) we obtain:

$c_{m n}\left\{\left[\left(\frac{m}{a}\right)^{2}+\left(\frac{n}{b}\right)^{2}\right]^{2}-\frac{\sigma \cdot h}{D} \cdot \frac{1}{\pi^{2}}\left(\frac{m}{a}\right)^{2}\right\}=0$

The equation of stability will be created for $c_{m n} \neq 0$ :

$\left[\left(\frac{m}{a}\right)^{2}+\left(\frac{n}{b}\right)^{2}\right]^{2}-\frac{\sigma_{c r} \cdot h}{D} \cdot \frac{1}{\pi^{2}}\left(\frac{m}{a}\right)^{2}=0$.

from which we obtain:

$\sigma_{c r}=\frac{\pi^{2} D}{b^{2} h}\left[m \cdot \frac{b}{a}+\frac{n^{2}}{m} \cdot \frac{a}{b}\right]^{2}$.

If we introduce the marks

$\alpha=\frac{a}{b} \quad$ i $\sigma_{E}=\frac{\pi^{2} D}{b^{2} h}$,

Then the critical stress $\sigma_{c r}$ is expressed via the Euler's stress $\sigma_{E}$ :

$\sigma_{c r}=\sigma_{E}\left(\frac{m}{\alpha}+\alpha \frac{n^{2}}{m}\right)^{2}$.

If the expression by which we multiply $\sigma_{E}$ is marked with $k_{m n}$, the critical stress is:

$\sigma_{c r}=k_{m n} \cdot \sigma_{E}$

$k_{m n}=\left(\frac{m}{\alpha}+\alpha \frac{n^{2}}{m}\right)^{2}$.

The minimum critical stress is obtained from minimum value of $k_{m n}$ while assuming that $n=1$ :

$\frac{\partial k_{m 1}}{\partial m}=0$

$\frac{\partial k_{m 1}}{\partial m}=2\left(\frac{m}{\alpha}+\alpha \frac{1}{m}\right)\left(\frac{1}{\alpha}-\alpha \frac{1}{m^{2}}\right)=0$,

from where:

$\left(\frac{1}{\alpha}-\alpha \frac{1}{m^{2}}\right)=0$

and so we have:

$\alpha=m=2$,

$k_{m 1}=\left(\frac{m}{\alpha}+\alpha \frac{1}{m}\right)^{2}=4$.

Which means that in this case $(n=1)$ :

$\sigma_{c r}=k_{m n} \sigma_{E}=k_{\sigma} \sigma_{E}=4 \sigma_{E}$.

The $k_{m 1}$ and $\alpha$ dependence can be presented for individual values of $m$ using appropriate curves, as shown in Figure 9:

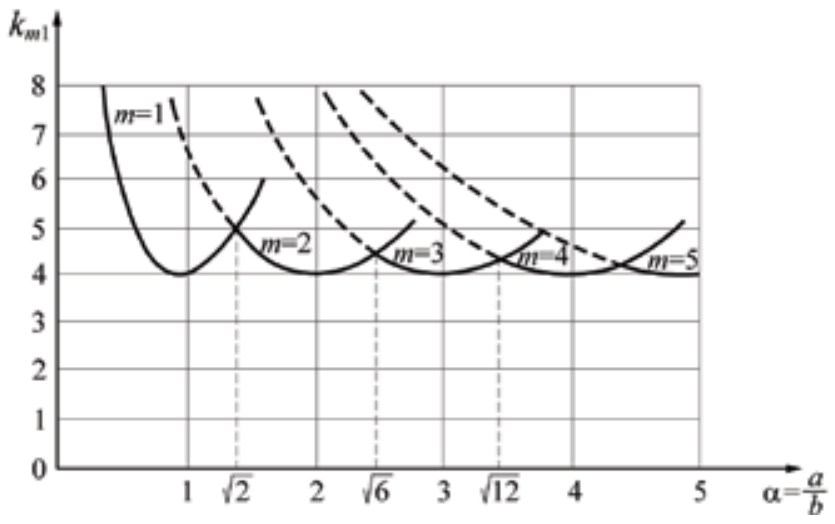

Figure 9. Diagram of curves showing dependence between $k_{m 1}$ and $\alpha$

Obviously, the smallest critical stress will be obtained when the a coefficient is a whole number. Thus, for instance, the buckling shape consisting of two half-waves (Figure 10) is obtained for the plate with the $\alpha=a / b=2$ ratio, and with $a$ uniform uniaxial compressive load.

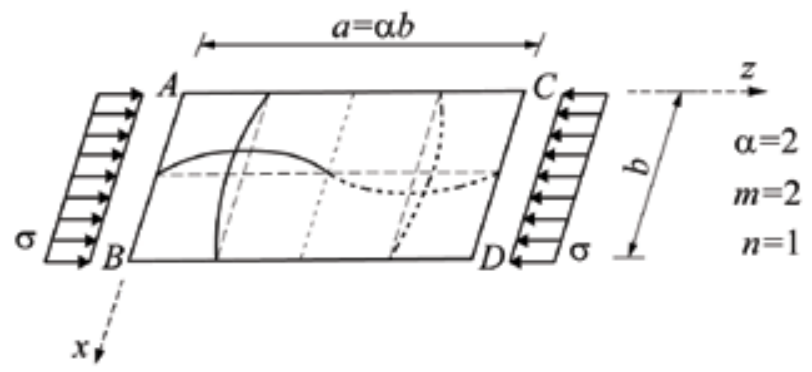

Figure 10. Buckling pattern

\section{Plate elements in compression according to EN 1993-1-1 and EN 1993-1-5}

It can be seen from the general theory of stability of plate girders (subsection 1.2) that the elastic critical buckling stress of plates is calculated using the following expression:

$\sigma_{c r}=\frac{k_{\sigma} \cdot \pi^{2} \cdot E}{12 \cdot\left(1-v^{2}\right)} \cdot\left(\frac{t}{b}\right)^{2}=k_{\sigma} \cdot \sigma_{E}$,

where:

$k_{\sigma}$ - plate buckling factor (coefficient), which takes into account the pinning conditions, distribution of stress over cross section (which is why the symbol is used), and plate length to width ratio, Figures 8 and 9a;

$t$ - thickness of steel plate elements (note: the general symbol $h$ has been used before the preceding expression, as this symbol is normally used in structural mechanics; however, the thickness of steel plate elements will from this point on be denoted by the symbol $t$, as introduced in Eurocodes for steel structures $[2,4]$ ); 
$\sigma_{\mathrm{E}}$ - Ideal buckling stress of the strip characterized by thickness $t$, width $b$ and length $L_{\text {; }}$

$v$ - Poisson ratio;

E - Elastic modulus.

Open cross sections are made of several plate elements that are free at one longitudinal edge, and are normally very long with respect to their width, cf. Figure 11.b. The buckling pattern of such external elements is shown in Figure 11.c. The dependence between the length to width ratio $L / b$ and the buckling factor $k_{\sigma}$ for a long thin external element free at one edge, is shown in Figure 11.d, from which it can be seen that the buckling factor $k_{\sigma}$ tends toward the limiting value of 0.425 with an increase in the $L / b$ ratio. The buckling factor $k_{\sigma}$ is dependent on boundary conditions and plate dimension ratios. Buckling factor $\left(k_{\sigma}\right)$ for several most frequent forms of stress exerted at plate element edges are presented in Table 2 [1], and this for great $L / b$ ratios of internal and external elements. The first step in determining the buckling factor $k_{\sigma}$ is the analysis of boundary conditions of elements, when we have to determine whether we are dealing with an internal or external element in compression. In the second step, the distribution of stress along the element's cross section is taken into account, and this through stress ratio at boundary fibres $\psi=\sigma_{2} / \sigma_{1}$. Most common cases are those involving element in compression with a uniform stress distribution ( $\sigma_{2}=\sigma_{1}$ ) when $\psi=1$, and when the element is subjected to pure bending with the stress at boundary fibres of equal but opposite signs $\sigma_{2}=-\sigma_{1}$, when $\psi=1$.

It has been shown that the buckling factor value $k_{\sigma}=4,0$, was a)

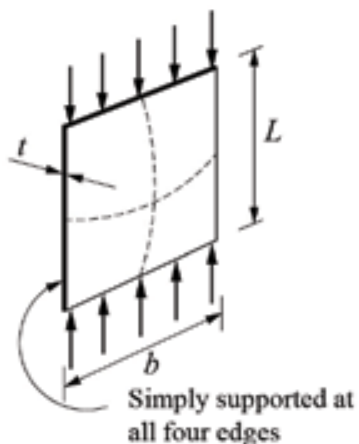

c)

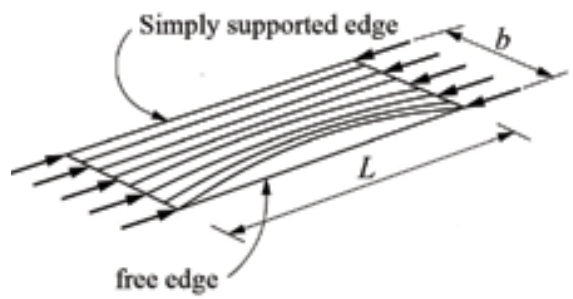

b)

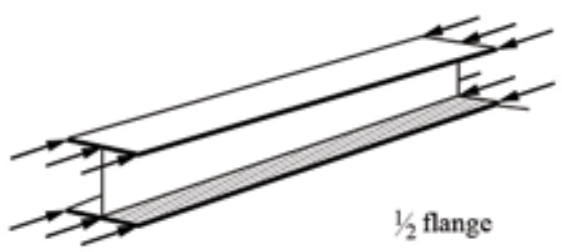

d)

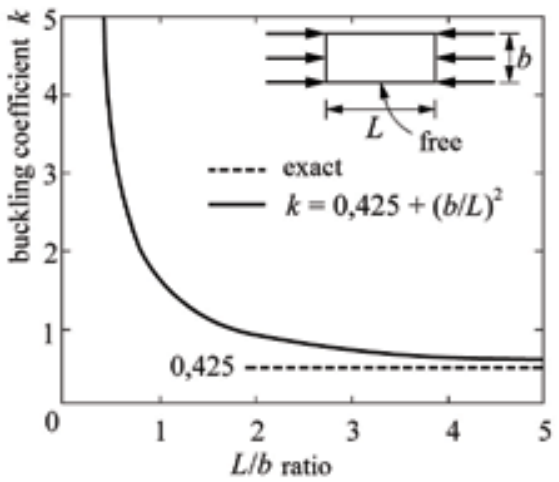

Figure 11. Behaviour of plate girders in compression [1]

Table 2. Values of buckling factor $\boldsymbol{k}_{\sigma}$ for several patterns of stress distribution at plate element edges [1]

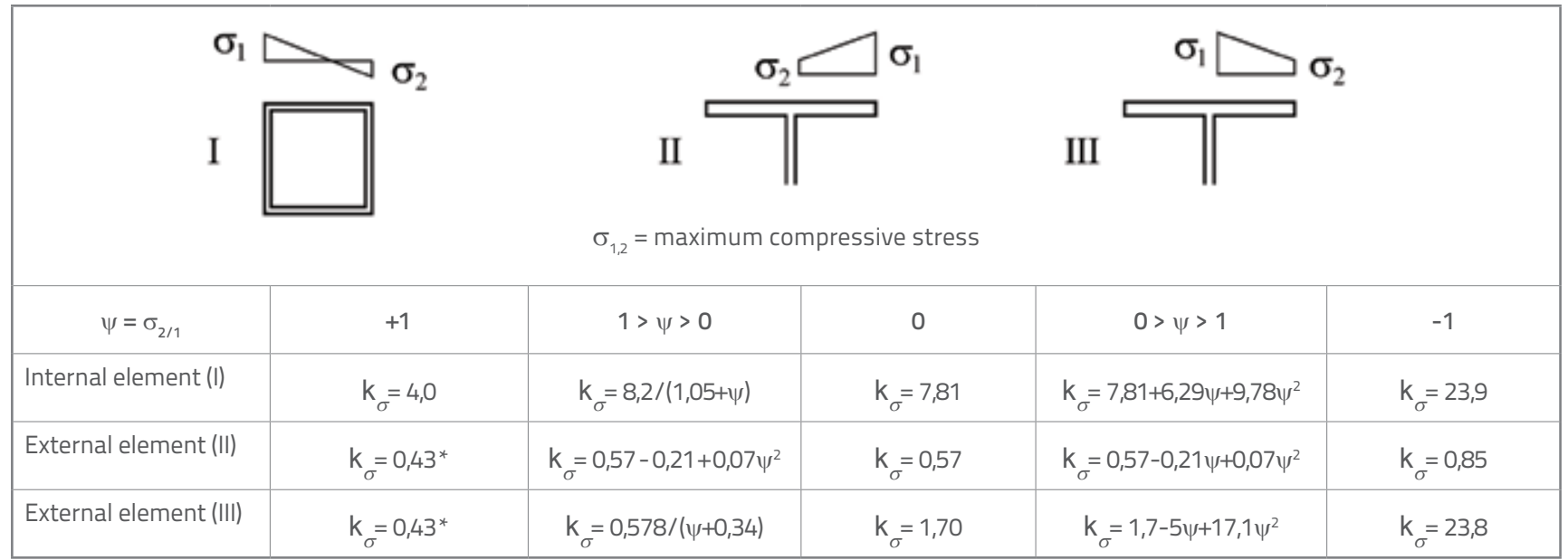

*also approximately obtained in Figure 11.d. 
first obtained analytically for boundary conditions and load as shown in Figure 8, while the same value for an internal cross sectional element and $\psi=\sigma_{2} / \sigma_{1}=1$ is given in Table 2 , and presented in Figure 12.

A diagram taken from literature [9] is shown in Figure 12. This diagram can be used to determine approximate values of buckling factor $k_{\sigma}$ for various boundary conditions and various plate length-to-width ratios. The diagram refers to the case $\sigma=$ const. only, It is applicable to plate girders without plate strengthening, and has been obtained using the previously presented thin plate theory.

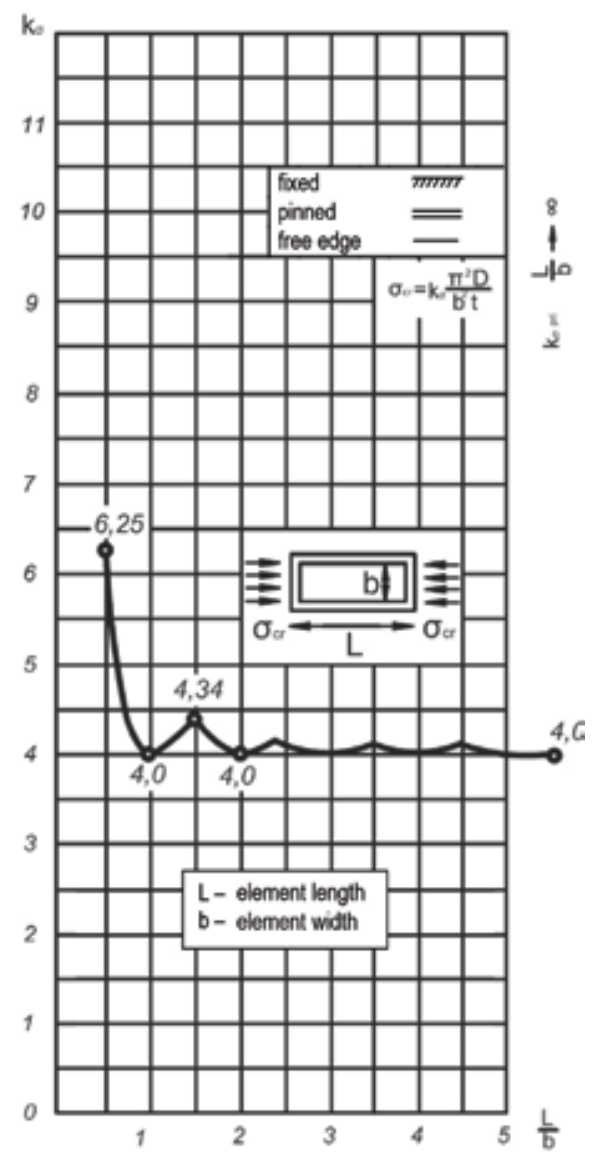

Figure 12. Values of buckling factor $k_{\sigma}$ for plate girder in compression, pinned from all sides

\section{Analysis of plate girders loaded in their plane using a specialized software package EBPlate Version 2.01}

An analytical procedure for obtaining the buckling factor and critical stress is presented in Section 2 in order to show how complex it is to solve even this relatively simple example. Other analytical methods can also be used for determining critical stress. One of them is the Rayleigh-Ritz energy method, where buckling patterns are also obtained using
Fourier series. This energy method is used in the EBPlate program [3] to calculate minimum values of critical stress $\varphi_{c r}$. The EBPlate program uses special program modules, such as the LAPACK (Linear Algebra PACKage), to solve eigenfunction problems $[5,10]$. Results obtained through EBPlate program were checked by comparing them with results of numerical analysis based on the finite element method (FEM), which was used to calculate some 330 examples for purposes of this comparison.

The European Committee for Standardization (CEN) has recognised the significance of standardizing the analysis and dimensioning of plate girders under compression, and has introduced a special standard EN 1993-1-5 [2] called PLATED STRUCTURAL ELEMENTS. To enable proper use of this standard, special comments and solved examples have been provided $[11,12]$. As the application of this standard is still relatively complex, a software called EBPlate [3] has been developed. This software is based on the theory of thin plates loaded in their plane. The software defines buckling factors and critical stress values as related to elastic buckling of plate girders of various boundary conditions, with or without strengthening of plates loaded in their plane.

The EBPlate software analyses isotropic or anisotropic plates of invariable thickness as shown in Figure 13. Basic input parameters for the use of this software, and final outcomes, are presented below:

- boundary conditions of the plate are first defined by selecting one of three possible cases: pinned edge conditions, fixed-edge conditions, and elastic conditions, as defined according to flexural stiffness and torsional stiffness values.

- longitudinal and transverse strengthening options, with similar or different properties, are defined (orthotropic plates),

- possibilities of using strengthening with closed cross section (e.g., trapezoidal cross section),

- external stress $(\sigma)$ distribution pattern is defined, as well as the possibility of inserting stress distribution data from an another software,

- the program calculates the minimum critical factor $\varphi_{c r}$ by which the external stress affecting the plate $(\sigma)$ is multiplied, so as to obtain the critical stress value $\sigma_{c r}$,

- the program defines all buckling patterns to which critical factor values are associated,

- 3-dimensional presentation of buckling model patterns,

- printout of results obtained during analysis, etc.

Thus, the following relation can be formed through the use of this software:

$\sigma_{c r}=k_{\sigma} \cdot \sigma_{E}=\varphi_{c r} \cdot \sigma$ 


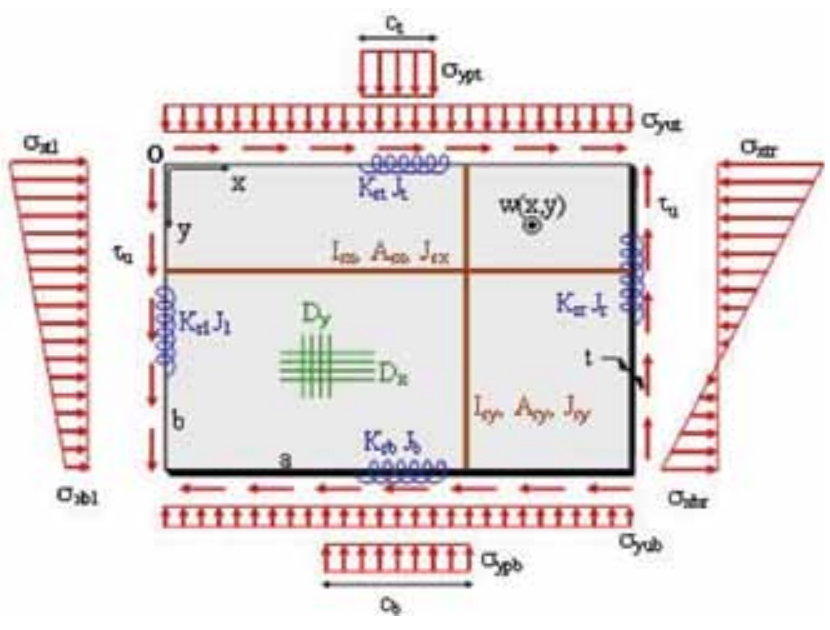

Figure 13. General presentation of EBPlate software input data

An example of the way in which buckling factor of the steel plate element shown in Figure 14 is calculated using the specialized software package EBPlate is presented below. First, the following data are defined: dimensions of the element, steel properties, and support conditions. The plate element shown in Figure 14 is freely supported at all four sides, without transverse and longitudinal bracing, which means that it is identical to the previously given analytical example, as shown in Figure 8 . The dimensions are: $a=2900$ $\mathrm{mm}, b=1650 \mathrm{~mm}, t=10 \mathrm{~mm}$. The element is subjected to the compressive stress of $\sigma=240 \mathrm{~N} / \mathrm{mm}^{2}$.

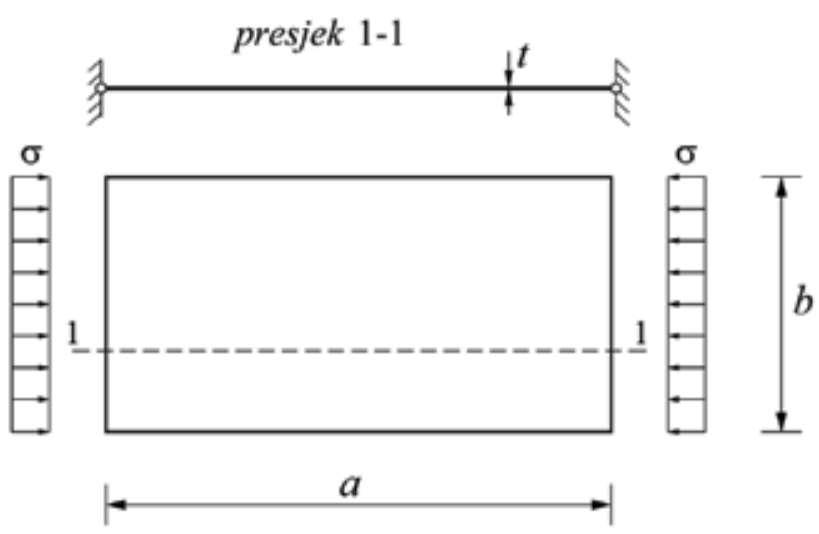

Figure 14. Definition of plate dimensions, boundary conditions and load

A uniformly distributed uniaxial compression load has also been applied to this rectangular plate, so that the result of the analysis can be compared with the analytic solution given in Subsection 1.2. The comparative presentation of results for this example, obtained analytically and using the EBPlate software, is presented in Figure 15.

The critical stress determined using this software was calculated by means of the theory of linear elastic buckling of idealized plate girders, so that there are no stress restraints that would normally be applicable in case of real elements.

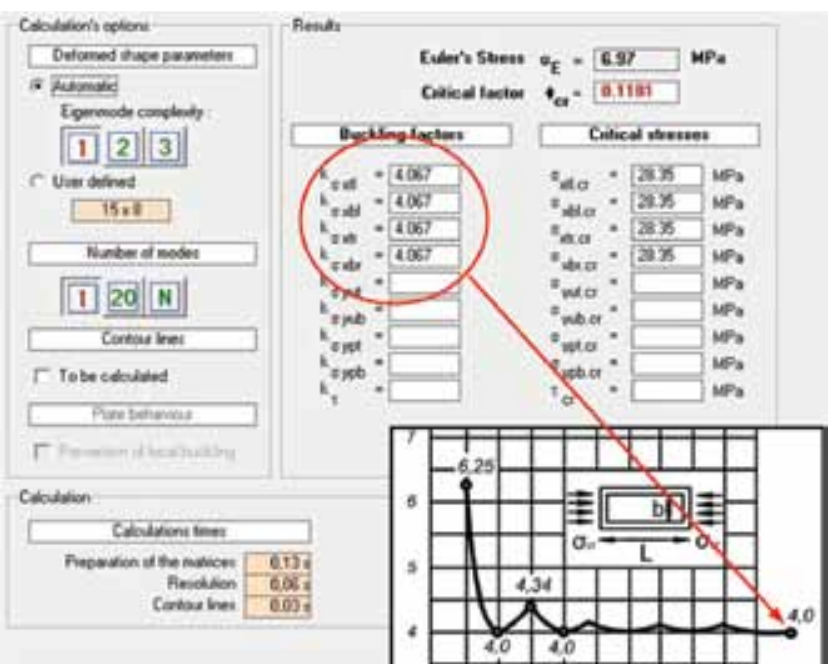

Figure 15. Presentation of software analysis results: buckling factors $k_{\sigma}$, critical stress factors $\boldsymbol{\Phi}_{c r}$ and critical stress values; comparison with buckling factor obtained by analytical procedure

In this example, the buckling factor amounts to $k_{\sigma}=4,067$ which is very similar to the value obtained by analytical procedure. Here, the critical stress (cf. Figure 15) amounts to:

$\sigma_{c r}=k_{\sigma} \cdot \sigma_{E}=\varphi_{c r} \cdot \sigma=4,067 \cdot 6,97=0,1181 \cdot 250=28,35 \mathrm{MPa}$

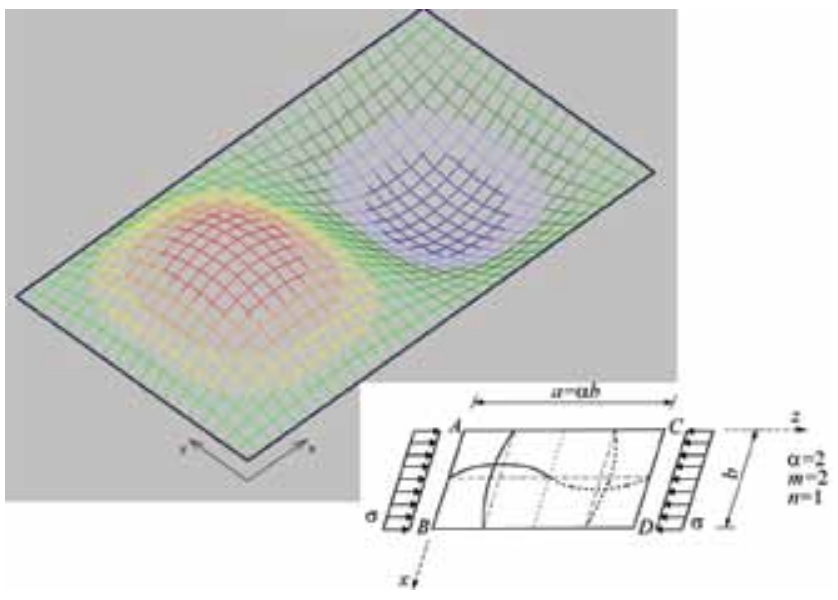

Figure 16. Buckling pattern generated by computer program; comparison with analytical procedure

A three-dimensional view of plate element subjected to buckling was generated by means of the EBPlate software. As shown in figure 16 , the buckling pattern is characterized by two waves in longitudinal direction ( $m=2$ ) and one wave in transverse direction $(n=1)$, and the result coincides well with the analytical solution presented in Figure 10

Obviously, examples from practice are not as simple as the example given in Figures 14 to 16, which only illustrates the way in which the EBPlate software generates buckling factor and critical stress values, without solving differential equation (4) for a concrete case. The importance of using the EBPlate program 
is best seen in calculating buckling factor and critical stress for complex practical cases, with orthotropic plates, when it is much more difficult to analytically define the buckling factor and critical stress values. Solutions for such complex cases are presented below. In such cases, it is first of all necessary to define the plate element geometry, boundary conditions, load and bracing position. Then the values of the buckling factor, $k_{\sigma^{\prime}}$ and the critical stress factor, $\emptyset_{c r}$ are defined for the case of local buckling, and also for the case of buckling of the entire plate element with bracing. The use of EBPlate software will be illustrated by a number of typical examples.

The first example is the plate element that is freely supported on all fours sides, with transverse bracing elements at $\sigma / 3$ (at both sides). The dimensions are $a=2900 \mathrm{~mm}, b=1650 \mathrm{~mm}, t=$
$10 \mathrm{~mm}, b_{s}=135 \mathrm{~mm}$, and $t_{\mathrm{s}}=8 \mathrm{~mm}$. The element is subjected to compressive stress of $\sigma=240 \mathrm{~N} / \mathrm{mm}^{2}$, cf. Figures $17 \mathrm{i} 18$.

The second example is the plate element that is freely supported on all four sides, with longitudinal bracing spaced at $b / 2$ intervals (one-side only). The dimensions are $a=2320 \mathrm{~mm}, b=740 \mathrm{~mm}, t$ $=15 \mathrm{~mm}, b_{s}=135 \mathrm{~mm}$, and $t_{s}=8 \mathrm{~mm}$. The element is subjected to compressive stress of $\sigma=230 \mathrm{~N} / \mathrm{mm}^{2}$, cf. Figures 19 and 20 .

The third example is the plate element that is freely supported on all four sides, with longitudinal bracing (trapezoidal cross section - one side only). The dimensions are $a=3600 \mathrm{~mm}, b=1700 \mathrm{~mm}$, $t=12 \mathrm{~mm}, b_{1}=150 \mathrm{~mm}, h_{\mathrm{s}}=140 \mathrm{~mm}, b_{2}=85 \mathrm{~mm}, b_{3}=630 \mathrm{~mm}$, $c=120 \mathrm{~mm}$, and $t_{\mathrm{s}}=8 \mathrm{~mm}$. The element is subjected to local compressive stress of $\sigma=470 \mathrm{~N} / \mathrm{mm}^{2}$, cf. Figures 21. and 22 .

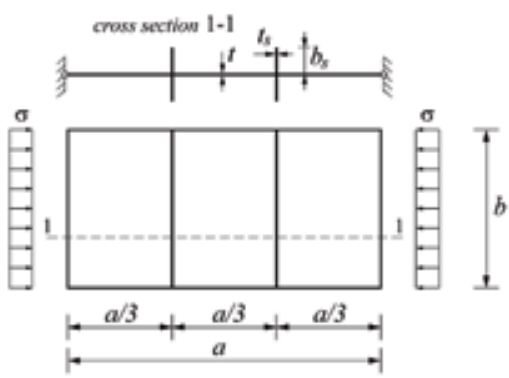

Figure 17. Definition of plate dimensions, boundary conditions and load

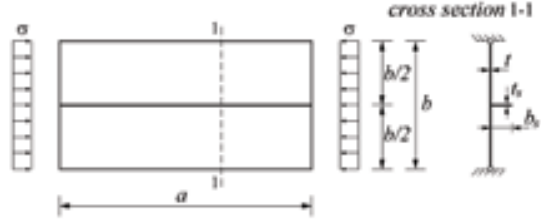

Figure 19. Definition of plate dimensions, boundary conditions and load

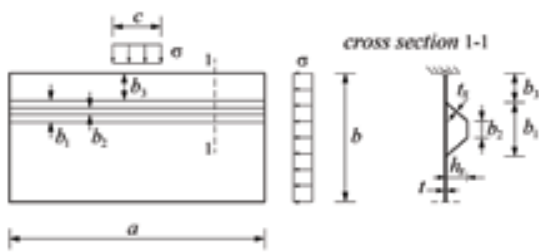

Figure 21. Definition of plate dimensions, boundary conditions and load

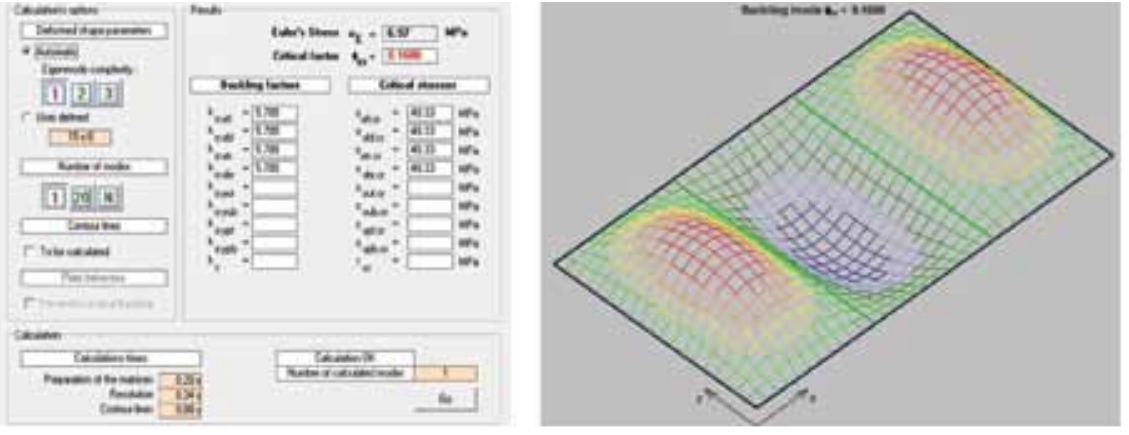

Figure 18. Buckling factor $k_{\sigma}$, critical stress factor $\square_{c r}$, and critical stress values, and the local buckling pattern
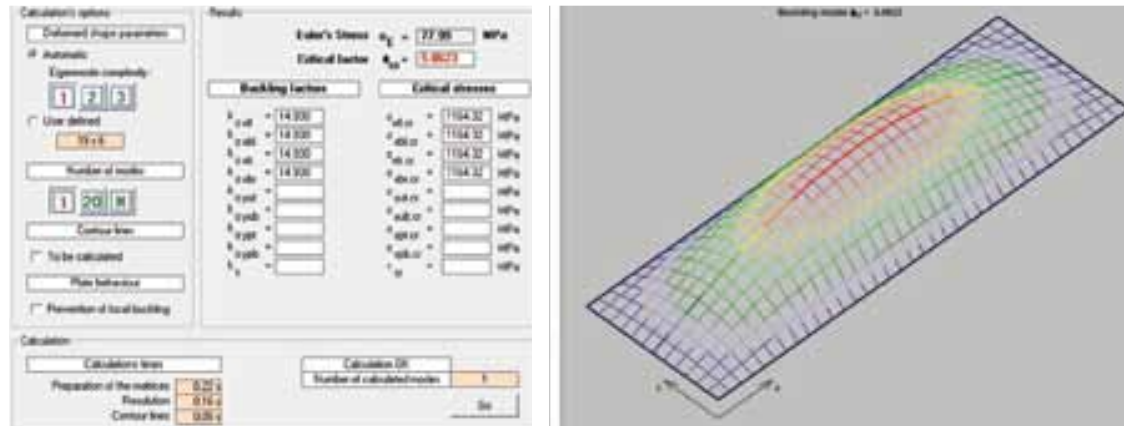

Figure 20. Buckling factor $k_{\sigma}$, critical stress factor $\Phi_{c r}$, and critical stress values, and the local buckling pattern
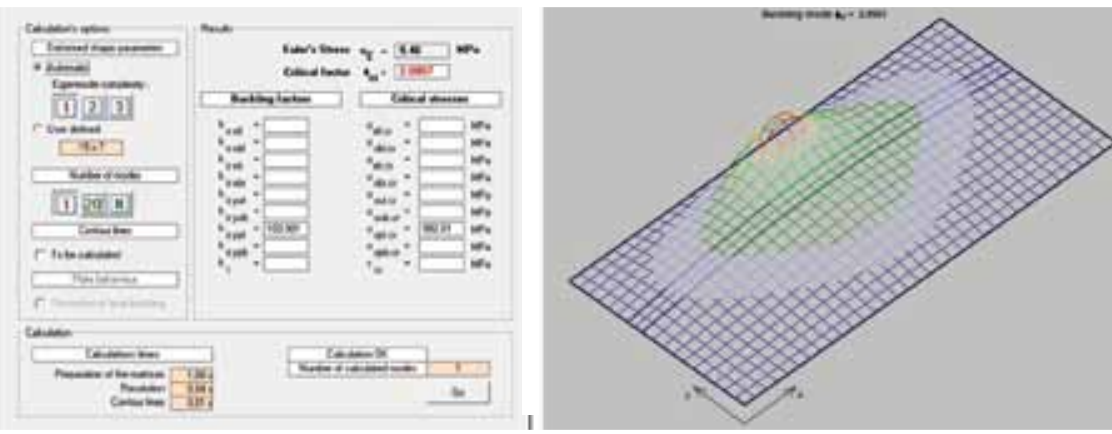

Figure 22. Buckling factor $k_{\sigma}$, critical stress factor $\Phi_{c r}$, and critical stress values, and the local and global buckling pattern 


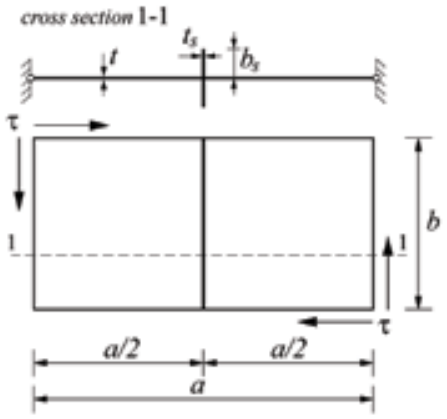

Figure 23. Definition of plate dimensions, boundary conditions and load

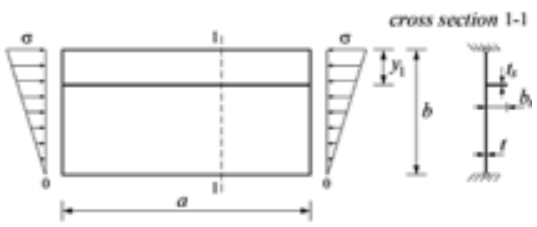

Figure 25. Definition of plate dimensions, boundary conditions and load

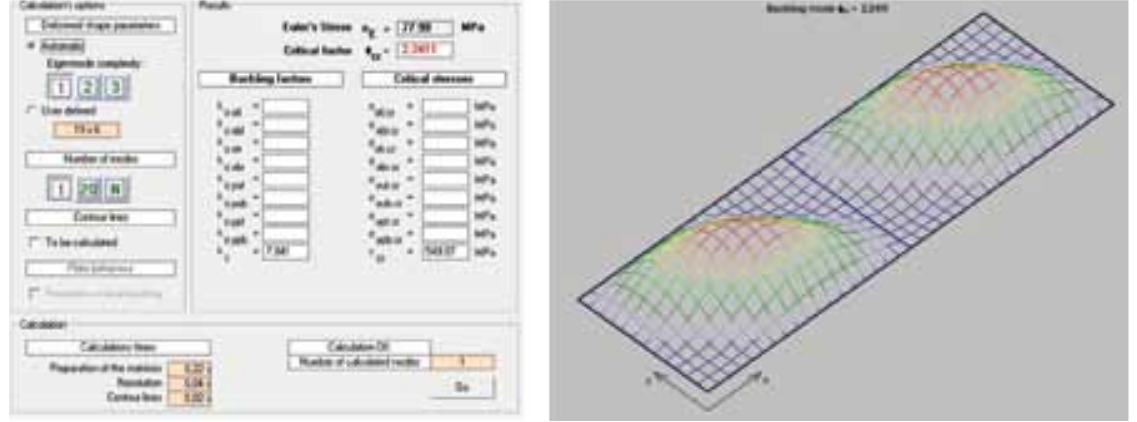

Figure 24. Buckling factor $k_{\sigma}$, critical stress factor $\Phi_{c r}$, and critical stress values, and the local buckling pattern

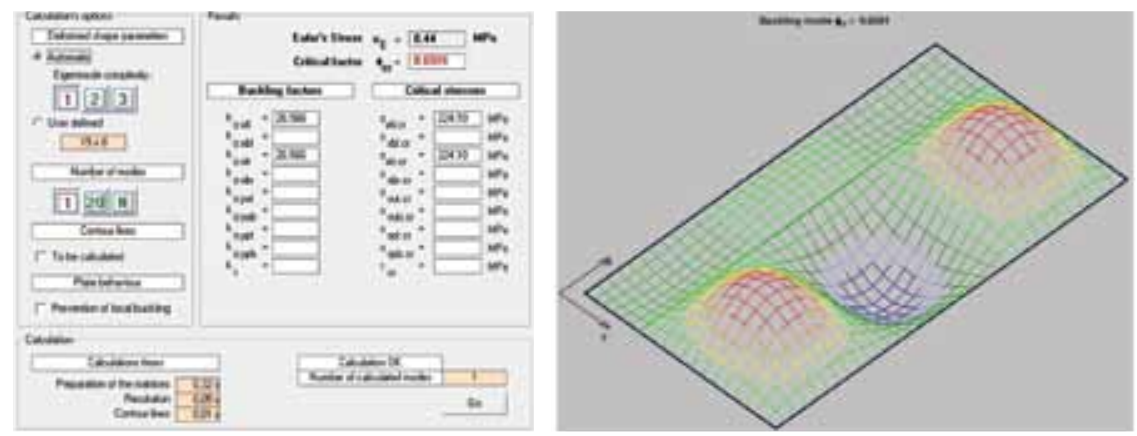

Figure 26. Buckling factor $k_{\sigma}$, critical stress factor $\Phi_{c r}$, and critical stress values, and the local buckling pattern
The fourth example is the plate element that is freely supported on all four sides, with transverse bracing at $a / 2$ (obostrano). Dimenzije su: $a=2320 \mathrm{~mm}, b=740 \mathrm{~mm}, t=15$ $\mathrm{mm}, b_{s}=135 \mathrm{~mm}$, and $t_{s}=8 \mathrm{~mm}$. The element is subjected to shear stress of $\tau=245 \mathrm{~N} / \mathrm{mm}^{2}$, cf. Figures 23. and 24 .

The fifth example is the plate element that is freely supported at all four sides, with one longitudinal bracing (one-sided). The dimensions are $a=3300 \mathrm{~mm}, b=1800 \mathrm{~mm}, t=12 \mathrm{~mm}, y_{1}=510$ $\mathrm{mm}, b_{\mathrm{s}}=220 \mathrm{~mm}$, and $t_{\mathrm{s}}=8 \mathrm{~mm}$. The element is subjected to bending with stress at the top edge: $\sigma=340 \mathrm{~N} / \mathrm{mm}^{2}$, cf. Figures 25 and 26.

Higher buckling factor values and, consequently, higher critical stress values (even exceeding failure limits $f_{y}$ ), have been obtained in the above cases. This is due to the fact that all instances of strengthening of the plate girder (taken as a whole) have been taken into account. The purpose of the bracing is to increase bearing capacity of the plate with regard to buckling action. It is significant to place bracing elements at precisely those places where they would be most useful. These examples show that longitudinal bracing is most efficient in case of compressive stress, while transverse bracing is most effective in case of shear stress. As to bending stress, the most efficient bracing is longitudinal bracing placed at about d/4 from compression edge.

Plates realized with bracing may show signs of local or global instability. Thus, depending on geometrical and static features, local plate buckling may occur in zones between bracing points (Figure 18), parts of braced plate may buckle at longitudinal and transverse bracing points, and global buckling of the braced place may also be experienced (Figure 20). According to critical load definition [5], the lowest critical stress value is always taken as the relevant value.

\section{Conclusion}

It is significant to show genesis of all important features arising from the theory of elasticity and theory of plasticity, which have been introduced in structural Eurocodes. For instance, two different ways to generate the expression for critical moment of lateral torsional buckling of members, given as a ready made solution in structural Eurocode [4], are presented in $[1,13]$. In this paper, the general theory of thin-walled plate girders is used to show the way in which the buckling factor $k_{\sigma}$, critical stress factor $\varphi_{c r}$ and critical stress values, are generated. The buckling factor $k_{\sigma}$ was obtained analytically by applying the plate buckling equation to the simplest case of buckling of the pinned rectangular plate subjected to uniformly distributed uniaxial compressive load. Approximately the same buckling factor $\left(k_{\sigma}\right)$ value can be taken, for the said boundary and load conditions, from diagrams given in literature [9]. The plate element, presenting the same boundary conditions and the same load as in the above mentioned case, was analysed using a special software 
package, and the results coincide with analytical solutions.

The advantage of using the EBPlate software lies in the fact that this software enables us to obtain the buckling factor and critical stress values for arbitrary boundary conditions and load, without or with plate girder strengthening. In other words, the solution can be obtained not only for cases given in Table 1, but also for cases of arbitrary support with bracing, and so all possible cases from structural Eurocodes [2] are taken into account.

A limited number of examples, obtained by analytical solving of differential equations for thin plate buckling, has so far been presented in literature. The issue of buckling has permanently been settled through the use of energy methods, and the results obtained using the EBPlate software are presented in such a way that we can relatively easily obtain buckling factor values, critical stress factor values, critical stress values, and the local buckling pattern for any boundary conditions, for arbitrary load, and for an arbitrary position of bracing. This paper also shows that significant notions, as introduced in structural Eurocodes for steel structures, can not be understood without proper knowledge of structural mechanics.

Note:

The research presented in this paper was conducted in the scope of the research project "Development of structures highly resistant to earthquake action" (114-0821466-1470), which is financed by the Ministry of Science, Education and Sport of the Republic of Croatia.

\section{REFERENCES}

[1] Androić, B., Dujmović, D., Džeba, l.: Čelične konstrukcije 1, IA projektiranje, Zagreb, 2009.

[2] Eurocode 3 - Design of steel structures - Part 1-5: Plated structural elements, EN 1993-1-5:2006 E, CEN - European Comitee for Standardization, 2006.

[3] Software package: EBPlate Version 2.01, 2007. www.cticm.com.

[4] Eurocode 3-Design of steel structures - Part 1-1: General rules and rules for buildings, EN 1993-1-1:2005 E, CEN - European Comitee for Standardization, 2005.

[5] Čaušević, M.: Statika i stablinost konstrukcija, Školska knjiga, Zagreb, 2003.

[6] Timoshenko, S., Gere, J.: Theory of Elastic Stability, McGraw-Hill, 1961.

[7] Markulak, D.: Posebna poglavlja čeličnih konstrukcija, Građevinski fakultet Sveučilišta Josip Juraj Strossmayer u Osijeku, Osijek, 2010.

[8] Hajdin, N.: Teorija površinskih nosača - ploče napregnute u svojoj ravnini, Građevinski fakultet, Beograd, 1979.

[9] Umanski, A.: Konstrukterski priručnik (izabrana poglavlja), Građevinska knjiga, Beograd, 1980.

[10] Kompjutorski softver: LAPACK, www. netlib.org/lapack/.

[11] Beg, D., Kuhlmann, U., Davaine, L. and Braun, B.: Design of Plated Structures, ECCS Eurocode Design Manuels, Ernst \& Sohn A Wiley Company, 2010.

[12] Johansson, B., Maquoi, R., Sedlacek, G., Müller, C., Beg, D.: Commentary and Worked Examples to EN 1993-1-5 "Plated Structural Elements", CEN - European Comitee for Standardization, 2007.

[13] Markulak, D.: Proračun čeličnih konstrukcija prema EN 19931-1, Građevinski fakultet Sveučilišta Josip Juraj Strossmayer u Osijeku, Osijek, 2008. 